\title{
1 CORINTHIANS 7:6-7: A CAVEAT AND A FRAMEWORK FOR 'THE SAYINGS' IN 7:8-24
}

\author{
Bruce W. Winter
}

\begin{abstract}
Summary
It is the case that, with verbs of saying, the neuter demonstrative pronoun ('this') often introduces the subordinate clause with an implied 'that' (as in, 'I say this, [that]...'). We contend that this same construction in 1 Corinthians 7:6 helps to unlock the pattern of Paul's thought in 1 Corinthians 7:8-24. 1 Corinthians 7:6 does not refer to the contents of 7:1-5, but emphatically to 7:7a where $\delta \varepsilon$ assumes an adverbial role of 'rather' in Paul's caveat. With the strong adversative 'but' ( $\left.\dot{\alpha} \lambda \lambda \alpha^{\prime}\right)$ in 7:7b he acknowledges that either singleness or marriage is a divine gift and then proceed to discuss aspects of these gifts and callings of God in 7:8-24.
\end{abstract}

There is diversity of opinion on the relationship of 1 Corinthians 7:6-7 to its wider context and, as a result, widely differing interpretations of 7:1-24 have been offered. The resolution of some of the alternatives narrows down to the

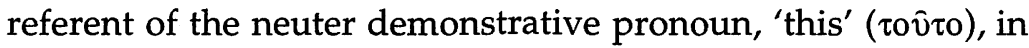
7:6. Commentators on 1 Corinthians have themselves seen how important 'this' is in determining the overall interpretation of the passage. Some have suggested that the neuter demonstrative pronoun refers to marriage in 7:2: 'But because of the temptation to immoralities, each man must have his own wife and each woman must have her own husband.' Thus they have concluded that Paul sees marriage as a concession to the lack of self-control and a less desirable option for Christians. ${ }^{1}$ Others see the phrase 'by way of concession' pointing to temporary sexual abstinence and 'this' refers to Paul's whole response $(7: 2-5)$ to the question raised by letter from the

1F. Godet, Commentary on the First Epistle to the Corinthians (Edinburgh: T \& T Clark, 1898) vol. 1, 325; W.H. Mare, 1 Corinthians (Grand Rapids: Zondervan, 1976) 229; and G.G. Findlay, St. Paul's First Epistle to the Corinthians (Grand Rapids: 1961) 824. 
Corinthian Christians (7:1). Paul is therefore seen to agree with what some see as the Corinthians' position on celibacy in 7:1.2 Others see this demonstrative pronoun referring back simply to $7: 5$, where Paul lays down the only grounds for not fulfilling conjugal obligations for those married. ${ }^{3}$

In this article it is proposed (I) to argue on grammatical grounds that the neuter demonstrative pronoun, 'this', when used with the verbs of saying as in 7:6, refers to the subordinate clause introduced by an implied 'that' (ö $\tau$ ) in 7:7a, and its place in the sentence emphasises the importance of the forward referent; and (II) to demonstrate that Paul's statements in 7:7b contain an over-arching conceptual framework for the discussion of God's gifts of singleness and marriage in the subsequent sayings in 7:8-16, and to show that he links these gifts with his standard teaching 'in all the churches' on other important issues of life such as the individual Christian's ethnicity and social status in 7:17-24.

It will be helpful at this point to identify the translation of 1 Corinthians 7:6-7 that this article is working towards and seeking to defend:

And this I am saying ( $\tau 0 \hat{\tau} \tau o \delta \dot{\varepsilon} \lambda \dot{\varepsilon} \gamma \omega$ ) by way of concession and not of command, [that] I wish rather $(\theta \dot{\varepsilon} \lambda \omega \delta$ ह́) all men were even as I myself, but ( $\dot{\alpha} \lambda \lambda \dot{\alpha})$ each man has his own gift from God, one after this manner, and another after that.

\section{The role of 'this' and ['that'] in 7:6-7}

In Greek grammar the neuter demonstrative pronoun, 'this'

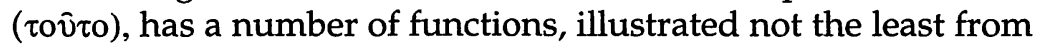
the Pauline corpus itself. It can refer to a neuter nominative or

\footnotetext{
2Including C.K. Barrett, The First Epistle to the Corinthians (London: A\&C Black, 19712) 157; F.F. Bruce, 1 and 2 Corinthians (London: Oliphants, 1971) 67; G.D. Fee (Grand Rapids: Eerdmans, 1987) 283-84; and most recently J.C. Poirier and J. Frankovic, 'Celebacy and Charism in 1 Cor. 7:5-7', HTR 89.1 (1996) 1-18.

${ }^{3}$ E.g. S.J. Kistemaker, 1 Corinthians (Grand Rapids: Baker, 1993) 214.
} 
accusative noun, pronoun, or relative pronoun. ${ }^{4}$ There are five instances where it agrees with the substantised infinitive or participle 5 and on some eighteen occasions in the Pauline letters it refers to a verb, thereby denoting action. ${ }^{6}$ It is also 'used as preparation for a subordinate clause' with ö $\tau$ understood in twenty-five cases. ${ }^{7}$ For example, in Romans 6:6 Paul says: 'and

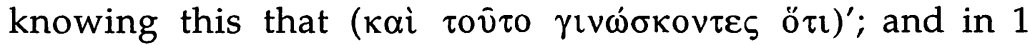
Corinthians 7:26 he writes: 'Therefore I think this...that it is

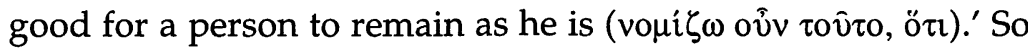
common was this usage in classical and koine Greek that the conjunction ö $\tau$ could be omitted before the subordinate clause, because $\tau 0 \hat{v} \tau$ o was sufficient to indicate it. For instance, in Galatians 3:17 Paul states: 'And this I am saying ( $\tau 0 \hat{\tau} \tau 0 ~ \delta \dot{\varepsilon} \lambda \dot{\varepsilon} \gamma \omega$ ) [that] the law...does not annul a covenant', where 'that' is simply understood. Elsewhere, we read in Ephesians 4:17: 'Therefore I am saying this in the Lord [that]...'. 1 Corinthians 7 itself provides an instance of the same: 'and this I am saying

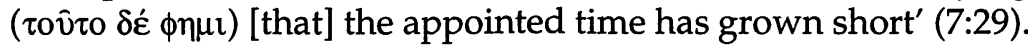
Accordingly, 'this' in 7:6 could well be preparation for the objective clause in 7:7.

It should also be noted that ö $\tau$ is used with the neuter demonstrative pronoun in Paul, as it is by other writers, 'when the clause which follows is to receive special emphasis' ${ }^{8}$ There are examples of this in 1 Corinthians, as in 1:12: 'And I am saying this that... $(\lambda \dot{\varepsilon} \gamma \omega \delta \dot{\varepsilon} \tau o v \tilde{\tau} \text { ö } \tau)^{\prime} .{ }^{9}$ The placing of the neuter demonstrative pronoun at the beginning of the sentence gives even greater emphasis to what was being said, as in 15:50: 'This I tell you, brethren, that flesh and blood will not inherit ( $\tau 0$ vิ

${ }^{4}$ Rom. 7:15 (twice), 16, 19, 20; 1 Cor. 5:2; 15:53-54; 2 Cor. 12:14; 13:1; Gal. 6:7; Eph. 5:32; 6:8; Phil. 2:5; or the substantive 1 Cor. 10:28.

${ }^{5}$ Rom. 14:13; 2 Cor. 2:1; 8:10; Phil. 1:22, 25. See BDF \#290 (3), \#413 (3).

${ }^{6}$ Rom. 12:20; 15:28; 1 Cor. 5:3; 6:6, 8; 7:37; 9:17; 2 Cor. 1:17; 8:20; Eph. 2:8; 6:1; Col. 3:20; 1 Thess. 4:3; 5:8; 1 Tim. 2:3; 4:16; 5:4; Philemon 18.

${ }^{7}$ BDF \#290 (3). Rom. 2:3; 6:6; 13:11; 1 Cor. 1:12; 7:26, 29, 35; 15:50; 2 Cor. 5:14; 9:6; 10:7, 11; Gal. 3:17; Eph. 4:17; 5:5; Phil. 1:7, 9, 28; Col. 2:4; 1 Thess. 4:15; 2 Thess. 3:10; 1 Tim. 1:9; 2 Tim. 1:5; 3:1.

${ }^{8} \mathrm{G} . \mathrm{B}$. Winer, A Treatise on the Grammar of New Testament Greek (Edinburgh: T \& T Clark, 1870) 200. In fact it could used without a verb for emphasis, i.e. 2 Cor. 13:9; Gal. 3:2.

${ }^{9} 1$ Cor. 7:26. See also Rom. 2:3; 2 Cor. 5:14; 1 Tim. 4:15; 2 Tim. 1:15. 
$\delta \varepsilon \dot{\varepsilon} \phi \eta \mu$, $\alpha \dot{\alpha} \delta \varepsilon \phi o i$, ö $\tau$...).'10 Where ö $\tau$ is implied, the neuter demonstrative pronoun occupies the emphatic first position in the sentence. ${ }^{11}$

The neuter demonstrative pronoun can also be followed by 'therefore' (iv $\alpha$ ) in final purpose clauses, as in Colossians 2:4: 'I am saying this in order that no one may delude you.' An important example is again provided in 1 Corinthians 7:35 where Paul stresses, 'I am saying this for your benefit not in

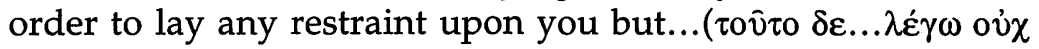
iv $\alpha \ldots \dot{\varepsilon} \pi \imath \beta \alpha \lambda \omega \dot{\alpha} \lambda \lambda \alpha \ldots)^{\prime}$. Here the neuter demonstrative refers back to 7:32-34 and iv $\alpha$ introduces the purpose clause containing the aorist subjunctive. However, the possibility that 7:7 is a final purpose clause is ruled out because of Paul's use of the present indicative, $\theta \dot{\varepsilon} \lambda \omega .{ }^{12}$

Also important to our discussion of 7:6-7 is the fact that ö $\tau$ is a conjunction used to 'introduce the objective clause after verbs of seeing or knowing, thinking or saying'.13 The following examples from the Pauline corpus demonstrate that this was not simply a classical Greek construction. 'Do you reckon this, O man, when you judge...that you condemn yourself' (Rom. 2:3); 'And knowing this, that...' (Rom. 6:6); 'And this I am saying, brothers, that...' (1 Cor. 15:50); 'having judged this, that...' (2 Cor. 5:14); 'he must reckon this again concerning himself, that...' (2 Cor. 10:7); 'such people must understand this, that...' (2 Cor. 10:11); 'For this we are saying to you,...that...' (1 Thess. 4:15); and 'we commanded this to you, that...' (2 Thess. 3:10). Verbs of saying followed by an objective clause assume the conjunction [ö $\imath$ ]. Again 1 Corinthians 7 provides examples: 'I am saying to the unmarried and widows [that]...' (7:8); and 'To the rest I am saying [that]...' (7:12). In $7: 6$, it is therefore grammatically possible that the verb 'I am

10Rom. 2:3; 6:6; 13:11; Eph. 5:5; 1 Thess. 4:15; 2 Thess. 3:10; 2 Tim. 3:1.

${ }^{11 E . g . ~} 1$ Cor. 7:29; 2 Cor. 9:6; Gal. 3:17; Eph. 4:17.

12In the discussion of final purpose clauses, BDF note that the use of 'the present indicate after ' $\mathrm{v} \alpha$ is, of course, only a corruption of the text' (BDF \#369 [6]). They are referring to variants found in some NT texts, but they do not include 1 Cor. 7:7.

13H.G. Liddel \& R. Scott, A Greek-English Lexicon (Oxford: Clarendon Press, $\left.1978^{9}\right) 1265$. 
saying' introduces an objective clause in the following verse, and the forward place of the neuter demonstrative pronoun in the sentence is meant to give special emphasis to what is to be said.

The particle used by Paul which begins the subordinate clause in 7:7 is not ö $\tau$, but either $\gamma \alpha \dot{\rho} \rho$ or $\delta \dot{\varepsilon}$ (there is textual uncertainty). ${ }^{14}$ If it were $\gamma \alpha \dot{\alpha} \rho$, then the sentence would read either 'I wish indeed ( $\theta \dot{\varepsilon} \lambda \omega \gamma \alpha \dot{\alpha} \rho) . .$. ', or 'to be sure I wish...'. ${ }^{15}$ However, the need to use 'indeed' to stress the fact seems unnecessary, given not only the use of $\tau$ vô $\tau$ for emphasis but its place at the beginning of the sentence, which highlights its importance even more.

If the correct reading is $\delta \dot{\varepsilon}$, then there are two possible translations. 'And this I am saying...that I wish all men were as even I myself am', where there is a causal connection which is less direct than $\gamma \alpha \dot{\alpha} \rho$. Given the preference of later Greek writers to replace $\gamma \alpha \dot{\rho} \rho$ by $\delta \dot{\varepsilon}, 16$ the later textual evidence for $\delta \dot{\varepsilon}$ would be explicable, but the textual evidence is certainly early ${ }^{17}$ and seems to rule this out.

If adverbial meaning was given to $\delta \dot{\varepsilon}$, 'rather', as some have suggested for this verse, 18 then it would fit in well with the concluding statement in the sentence, as well as the use of $\tau$ ov $\tau$ with $\lambda \dot{\varepsilon} \gamma \omega$ and an implied ö $\tau$. The verses would read: 'And this I am saying by way of concession and not command, [that] I wish rather all were as I myself.'19 Paul goes on to

${ }^{14}$ B.S. Rosner, Paul, Scripture and Ethics: A Study of 1 Corinthians 5-7 (Leiden: E.J. Brill, 1994) 151-52.

15See BAGD \#4 on the use of $\gamma$ ó $\rho$ to mean 'indeed' or 'to be sure'.

16 Ibid.

${ }^{17}$ E.g. P46.

${ }^{18}$ On the meaning 'rather' in relation to this verse, see Winer, $A$ Treatise on the Grammar of New Testament Greek, 567. See also J.D. Denniston, The Greek Particles (Oxford: Clarendon Press, 1950²) 162 and 177 on the adverbial use of $\delta \dot{\varepsilon}$. K. Callow, 'The Disappearing $\delta \dot{\varepsilon}$ in 1 Corinthians', in D.A. Black (ed.), Linguistic and New Testament Interpretations: Essays on Discourse Analysis (Nashville: Broadman Press, 1992) ch. 9, analyses the occurances of $\delta \varepsilon$ in 7:1-9 and notes the short-span contrast in 7:7b, but she ignores the particle in 7:7a altogether (187).

${ }^{19}$ B.M. Metzger, A Textual Commentary on the Greek New Testament (London and New York: United Bible Societies, 1971) 554 argues: 'The reading $\delta \dot{\varepsilon}$, which is strongly supported, is preferable to $\gamma \alpha \dot{\rho} \rho$ which appears to be a 
observe in a statement introduced by the strong adversative, 'but ( $\dot{\alpha} \lambda \lambda \dot{\alpha})$ each one has his gift from God, one of one kind and one of another'. He recognises that alternatives open to Christians are not a matter of preference, but are a personal gift from God for each individual.

There is an interesting near parallel construction in 7:2526. After stating in 7:25 that he has no command from the Lord, he goes on to say in 7:26: 'I think therefore this to be good because of the present distress that it is good' $^{20}$ In 7:6-7 and $7: 26$ verbs of saying or thinking introduce the subordinate clause; although ö $\tau$ is absent in the former, it is present in the

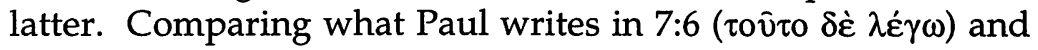

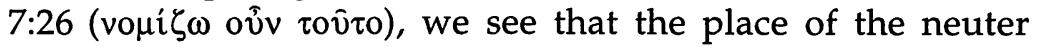
demonstrative in 7:6 puts stress on the Pauline concession which follows, while in 7:26 it introduces Paul's own conviction, as the subsequent discussion demonstrates. In 7:26 the connective ov v makes it clear that the reference is forward, while in 7:6 the emphatic placing of the neuter demonstrative pronoun indicates the same.

According to Hans Conzelmann, the imperitival aspect of 7:6-7 'must not be pressed'. ${ }^{21}$ But the interpretation of 7:6-7 offered here has the advantage of giving proper weight to the

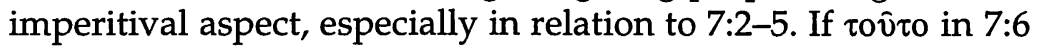
refers back to those verses as a kind of concession, then Paul case would be fraught with difficulties. These verses clearly include commands: 'each man must have his own wife'; 'each woman must have her own husband'; 'the husband must render to his wife his [sexual] obligation, and likewise also the wife must render to her husband [her sexual obligation]'; and 'You

correction introduced by scribes who did not appreciate the nuance of opposition to the concession mentioned in ver. 6.' The discussion here would rule out the view of v. 6 containing a concession.

${ }^{20}$ The verb followed by accusative and the infinitive, $B A G D$.

${ }^{21} \mathrm{H}$. Conzelmann 1 Corinthians (Philadelphia: Fortress, 1975) 118. See D.E. Garland, 'The Christian's Posture towards Marriage and Celibacy: 1 Corinthians 7,' Rev.Exp. 80 (1983) 360 n. 23 on the imperatives, citing W.F. Orr, 'Paul's Treatment of Marriage in 1 Corinthians 7,' Pittsburg Perspective 8 (1967) 12. Garland concludes that the reference of 7:6 is forward and not backward, but feels that if $\gamma \alpha \dot{\alpha} \rho$ was the correct reading, then that verse would clearly refer forward to v. 7 . 
must not defraud one another'. The referent of $\tau$ ov $\tau$ o in 7:6 cannot be the plurality of commands in 7:2-5, since the neuter demonstrative pronoun is not plural $(\tau \alpha \hat{v} \tau \alpha)$, a form Paul uses elsewhere to refer to pluralities. Again 1 Corinthians itself provides examples of this: 'I write these things ( $\tau \alpha \hat{v} \tau \alpha)$ ' (4:14); 'I am not saying these things ( $\tau \alpha \hat{v} \tau \alpha)^{\prime}$ (9:8); and 'I am not writing

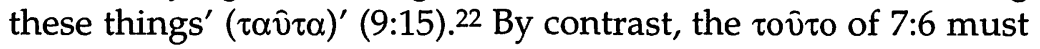
refer to a single phenomenon. ${ }^{23}$ As has been shown, there are

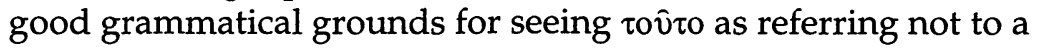
previous imperatival verb; the concessive comment that follows stresses that, in contrast to $7: 2-5$, he is not commanding conduct in 7:6-7, although he will again do so in 7:8-24.

It is suggested here, then, that Paul in 7:6 is at pains to inform his readers in this way: 'And this I am saying by way of

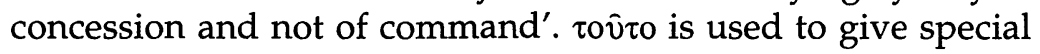
emphasis to what he is about to say (which is not a command) and, as we have noted, it is positioned at the beginning of the

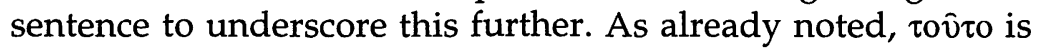
normally proceeded by 'that' (ö $\tau$ ), although here, as in 1 Corinthians 7:29, the conjunction is understood. The referent of the neuter demonstrative pronoun, then, is forward looking, and its place in the sentence furthers the emphatic nature of Paul's concessive comment in the clause in 7:7: '[that] I wish rather all men were as even I myself.'

\section{The role of $7: 7$ in $7: 8-24$}

Paul recognises that, whatever the advantages of singleness, his 'wish' can never be his 'command' that is binding on all the Corinthians, because of the alternative gifts God gives to his people. What, then, is the place of 7:7 in the subsequent discussion? It appears to operate as the over-arching reality in which the implications of those two callings represented by two different gifts of God for Christians are subsequently worked out. How Paul discusses the issues in 1 Corinthians 7 helps us to understand this. The matter that the Corinthians have

22The exception is 12:20, where he is citing the LXX.

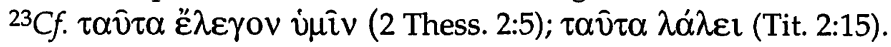


themselves raised by letter in 7:1, and that Paul has dealt with in $7: 2-5$, is consciously distinguished from the rest. He makes it clear that he is now taking up issues on his own initiative, and not ones raised by them: 'this I am saying ( He himself is raising three related issues: 'I am saying ( $\lambda \dot{\varepsilon} \gamma \omega \delta \dot{\varepsilon})^{\prime}$ (7:8); 'I am commanding ( $\pi \alpha \rho \alpha \gamma \gamma \varepsilon \dot{\varepsilon} \lambda \omega)$, not I but the Lord'

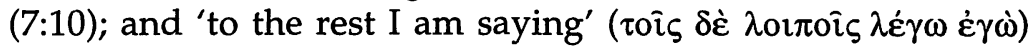
(7:12). What he is discussing is clear-viz. singleness and marriage in relation to the widows and the unmarried (7:8-9), separation and reconciliation (7:9-10), and the marriage ordinance and divorce for those whose marriage partners are not Christians (7:11-16).

Before Paul deals with the next issue raised by the Corinthians' letter to him (7:25ff.), he concludes the whole discussion by repeating a summary of a major aspect of Paul's traditional teaching which he commanded, without exception in 'all the churches' (7:17-24). It begins with the statement: 'As the Lord has assigned to each, each as God has called, thus he must walk.' Ethnicity and social identity were the results of the providential oversight of God $(7: 18,21,23)$. Having stated this at the beginning of the passage, Paul repeats the command twice 'each in whatever calling, brethren, in this you must remain with God' $(7: 20,24)$. Just as the gifts of singleness or marriedness is personally given by the Lord, so too, Paul seems to be implying, were these ethnic and social 'markers'. God's gifts and calling were personal, and Christians were to remain in the situations in which God had placed them. This meant that Christians were forbidden to undergo epispasm, circumcision or to sell themselves into slavery, for they changed their God-given cultural or social status $(7: 18,23)$. These moves were undertaken in the first century for financial reasons or to overcome feelings of social stigma imposed by secular society. ${ }^{24}$ Together with an individual's marital status, they were personal 'gifts' or 'callings' from God. In this context the word for 'calling' ( $\kappa \lambda \hat{\eta} \sigma \iota \varsigma$, which can also mean 'class') is a synonymous term for gifts used in 7:7. So sandwiched between

${ }^{24}$ For a discussion of 7:17-24, see my 'Social Mobility' in Seek the Welfare of the City, First Century Christians in the Graeco-Roman World (Grand Rapids and Carlisle, Eerdmans and Paternoster, 1994) ch. 8. 
7:6 and 7:17-24 are supplementary but very important issues, all of which Paul himself raises and which he relates to the gifts distributed to the individual by God himself.

\section{Conclusion}

The resolution of the function of the neuter demonstrative pronoun has been shown to be crucial for interpretating this passage. The failure to understand its grammatical role is, in part, due to the lack of a thorough treatment of the use of this pronoun by New Testament grammarians. Here, as in other places in the Pauline corpus and elsewhere in the New Testament, insufficient attention has been given to it. In some cases, important points of interpretation can hang upon an understanding of its function. Its role is certainly crucial in 1 Corinthians 7:6-7, for it occupies a pivotal place as Paul turns from the Corinthian request for an apostolic ruling in 7:2-5 to the apostolic and dominical sayings in 7:8ff., inserting his own 'concession' in 7:6-7a. ${ }^{25} \mathrm{He}$ then proceeds in 7:7b to provide the framework for the discussion of Christian conduct in relation to the different gifts and callings of God.

25For a discussion of 1 Cor. 7:1-5 and 7:25-40, see my After Paul left Corinth: The Impact of Social Ethics and Social Change (forthcoming, Eerdmans) ch. 7,8 and 9. 